\title{
震災からの住宅復興対策のための事前需要推計に関する基礎的研究 \\ A BASIC STUDY ON ESTIMATION OF DEMANDS FOR PREPAREDNESS \\ OF HOUSING RECOVERY FROM EARTHQUAKE DISASTER
}

\author{
池田浩敬*，中林一樹** \\ Hirotaka IKEDA and Itsuki NAKABAYASHI
}

\begin{abstract}
The Hanshin-Awaji Earthquake clarified the importance of preparedness of housing recovery and urban reconstruction. This is a basic study on the construction of methods for estimation of demands for the preparedness of shelter and housing recovery measures after the next earthquake disaster. The questionnaire survey was made at main cities in Shizuoka prefecture, where the Tokai Earthquake of M.8 shall occur in the near future. The purpose of this survey is to clear the demands of shelter and housing recovery for residents after the earthquake. The results are as follows; 1)the elderly and the people of low income need a shelter much more. 2)The renters of private houses, the elderly and people of low income need not only temporary houses but also temporary stay in the public houses after a sheltering. 3)The renters need the public houses very much for a permanent housing. The estimation methods will be able to be built through these analyses, which give the parameters for estimation models.
\end{abstract}

Keywords: Housing Recovery Process, Earthquake Disaster, Character of Inhabitant, Estimation of Demand, Questionnaire Survey

住宅復興過程, 震災, 居住者特性, 需要推計, アンケート調査

\section{1. 研究の背景と目的}

(1) 研究の背景

災害対策においては、被害の発生自体を防止或いは軽減するため の予防対策が重要であることは言うまでもない。しかし、ハード整 備を伴う地域の防災性向上のための対策効果は一朝一夕には顕在化 しない。他方、地方公共団体が被災後迅速かつ円滑に適切な復興計 画の策定、復興対策の実施等を行うことがより重要となってきてい る。従って、特に大規模な災害の発生が予想されている地域では、 予防対策に掛かる時間的な制約もあり、予防対策と並行し、発災後 の復興対策を迅速かつ的確に行えるよう、事前に想定される被災を 前提とした復興対策の検討・準備を行っておくことが必要である。

阪神・淡路大震災などの近年の大規模な災害の経験と防災をめぐ る社会構造の変化等を踏まえ、平成 7 年に抜本改定が行われた新し い防災基本計画においても迅速かつ円滑な災害復旧 ・ 復興への備え の必要性が謁われている。

一方、被災後の復興対策に関する具体的な検討を事前に行うため には、地震、火山、洪水など予想される災害に関する自然現象の想 定と物的な被害想定と合わせ、被災者の復興対応及びそれに伴う対 策需要を予め想定しておくことが必要となる。多様な復興対策需要 のうち、特に被災者の生活再建の基本となる住宅確保に関する対策
需要を予め想定しておくことは、被災者の生活再建支援対策全体を 事前に検討する上で重要な要素となる。

また、阪神・淡路大震災においては、震災後であっても避難者数 の把握や応急住宅対策、災害復興公営住宅の建設等恒久的な住宅対 策需要の正確な推計を行うことは困難を極めた。つまり、実際に災害 が起きた後も、混乱期に復興計画を検討していくには、住まいの復 興对策をニーズに的確に対応し、かつ迅速に行う上で対策需要量の 推計は必要不可欠であると考えられる。

こうした背景の下、国土庁を中心に事前復興計画(2) 注1)に関する 検討を進めてきたが、近年地方公共団体等が実施した地震被害想定 においても、地震災害時の住宅復興に関する対策需要の想定を試み るようになってきている。静岡県では、1994年の地震被害想定" に おいて、短期的、長期的な避難生活人口の想定を行っているととも

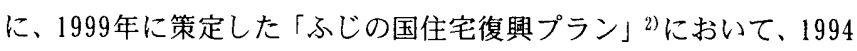
年の地震被害想定結果に基づき災害復興公営住宅等の低家賃の賃貸 住宅への入居を希望する被災者数の想定を試みている。

しかしながら、想定される被害の程度及び当該地域における居住 世帯及び住宅の特性と対策需要量との関係に関する把握は十分にな されていない。以下にこれまでに行われてきた震災時の住宅復興対 策需要の事前推計に関連する研究について概観した。

\footnotetext{
* 東京都立大学大学院都迌科学研究科 大学院生・工修 Graduate Student, Graduate School of Urban Science, Tokyo Metropolitan University, M. Eng.

** 東京都立大学都市研究所 $\cdot$ 大学院都市科学研究科 教授. 工博

Prof., Center for Urban Studies and Graduate School of Urban Science, Tokyo Metropolitan University, Dr. Eng.
} 
(2) 既往の研究状況

木村・林他の研究3)4 では、震災時に兵庫県内の阪神・淡路大震災 の被災地に居住し、被災後県内にとどまった人及び県外へ移動した 人を対象としたアンケート調查に基づき、震災直後から震災後半年 までの間の 4 時点における住宅及び居住地の選択と当該居住者の属 性、被害の程度等之の対态関係に関寸る検討を行っている。平山・ 木山の研究(5)、福留・中林の研究6)では、阪神・淡路大震災における 住宅再建の実態について従前の住宅の特性等との関係から分析を行 っている。室崎の研究》では、住宅被害の大きかった神戸市、芦屋 市、西宮市に居住していた人を対象とした住宅確保等に関する意向 調查を行い、阪神・淡路大震災における住宅再取得過程上その支援 方策に関する検討を行っている。また、池田・中林の研究早では、 居住者の世帯属性、住宅被害の程度と住まいの復興対応との関係把 握に基づく住宅復興対策需要の事前推計に関す万方法論の提案を行 っている。しかし、このうち室崎の研究、池田・中林の研究以外の研 究で扱っている住まいの復興過程とその対応実態は、あくまで当該 事例に㧍ける対策供給側の量的、場所的、質的な制約条件の下での 選択の結果であり、対策需要量そのものではない。また、室崎の研 究は、阪神・淡路大震災における有效な住宅復興支援方策の検討を 目的とし、池田・中林の研究は、事前推計に関する方法論の提案を 目的としておう、両者とも震災以前の世帯属性と対态意向上の関係 の把握を目的上はしていない。

このように、これまでにも震災後の住まいの復興対応に関する事 例研究は行われてきているが、扱われている住宅復興対忘は、あく まで当該事例における対応実態であり、対策供給側の各種の制約条 件が異なるとどのように変動するのかといった点までを考慮した对 策需要量そのものではない。被害程度・世带特性と住まいの復興対 応意向との間の定量的な関係把握については、まだ十分には行われ ていない。

(3) 研究の目的

本研究では、東海地震の発生が想定されている静岡県の中でも特 に、住宅の密度、土地・住宅のストック、被害の集中度合い等から 震災後の住宅復興対策が課題となる都市部を調査の対象地域上し、 将来の地震に備えたあるいは地震発生直後の早期需要推計のための モデル構築に向け、居住者の特性及び住宅被害の程度等上被災後の 対応意向との関係を明らかにすることを目的として検討を行った。

\section{2. 住まいの復興対応のフレーム}

(1) 住宅復興対策需要推計のフレーム

震災後の被災者の住宅復興対策計画を検討する際には、まず住宅 の被害量及びそこに居住していた世帯の特性に対応した住宅復興対 策需要（潜在需要）を把旺し、その上で、予算、用地等の対策供給 側の制約条件を加味し効果的かつ実現可能な対策の立案を行う必要 がある。しかし、震災直後に、住宅被災世帯の正確な量、その属性等 を把握し、従前の居住地以外の場所に移動した被災者も含め住宅に 被害を受けた被災者に対する意向調查を行うことは大きな困難を伴 う作業である。特に市街地の復興を視野に入れた場合、地域別の住 宅復興需要の把握が求められる。このことに対応して、予め被害想 定や地域危険度評価によって家屋の大きな被害の危険性が指摘され ている地域において、世帯属性・住宅の被害の程度と震災後の住宅
の復興対応意向との関係、復興住宅の建設場所による需要内容の変 化などを把握しておくことにより、事前あるいは地震発生後の比較 的早い段階で住宅復興需要の推計を可能とすることが出来れば、単 なる戸数の計画だけでなく住宅配置計画という側面在加味した住宅 復興対策計画の迅速かつ的確な策定に資与る事になると考えられる。 （2）住まいの復興対応の選択肢の設定

被災後の住宅復興対策需要推計の基本となる、住まいの復興対㐫 に関する住民の選択肢を以下のように設定した。当該選択肢の設定 に当たっては、阪神・淡路大震災において実施された被災者の住宅 復興支援策とともに、同震災の被災地の従前の居住者、忘急仮設住 宅の入居者等の、地震発生後の避難や住まいの確保等住まいの復興 プロセスに関寸る実態及びその後の対态意向について把握を行った アンケート調査結果等 3）7）9１１0）に基づき、地震発生後の時間経過を 以下の3 時点に区分し、それぞれの時点における住宅属性别、被害程 度別の対夋の選択肢を図 1 のように設定した

a) 緊急避難先の確保（地震発生直後～ 1 ケ月後程度）

行政が設置した避難所、親族・知人宅、勤務先が提供寸る施設一 の避難、屋外避難等の緊急避難刘応。

b) 応急住宅の確保（1 ケ月後 1 年後程度

行政が建設した応急仮設住宅へに入居、自力仮設住宅の建設、賃 貸住宅一の入居等応急的な住宅の確保対応。

c) 恒久住宅の確保（1 年後以降）

持ち家の自力再建、低家賃の公営住宅への入居、民間の貨貸住宅 八の入居等恒久的な住宅の確保対灾。

\section{3. 住まいの復興対応意向調査}

東海地震の発生が想定されている静岡県の中でも特に、被害が集 中的発生し、住宅の密度、土地・住宅のストック等からも、震災後 の住宅復興対策が課題となると考えられる都市部を母集団として設 定した。具体的には県内で人口が 20 万人を上回っている静岡柿、 浜松市、清水市、沼津市、富士市の 5 大市の中で県が実施した地震 被害想定結果 1) 亿执いて建物被害率注1)が $30 \%$ 在上回る 508 町丁目 のうち世帯数注2 が 100 末満の町丁目を除く 362 町丁目の中から 100 町丁目を等確摔抽出し、抽出された町丁目から比例抽出により 2400 世帯を抽出注3)した。

抽出された世帯を対象に、想定される東海地震により現在居住し ている住宅が被災した場合に、地震発生後の各段階で、住まいの復 興に関しどのような対応をとるかということについて、住宅の被害 の程度別の対応に関する意向調查を行った。

1 年のうち人々の防災への関心が比較的高まると考えられる「防 災の日」の時期に合わせ 2000 年 9 月に実施した。

抽出した世帯のうち、宛先不明・転居等で末達のものが 410 票あ り、配布数は 1990 票、回収数は、1071 票（回収率 53.8\%）、うち 有効回収数は 1046 票（有効回収率 $52.6 \%$ ）であった。注4)

本調査では、住宅の所有形態別では、持ち家世帯 905 世帯、借家 世帯 131 世帯から回答が得られた。

\section{4. 被害程度・世帯特性と時系列別の対応行動との関係}

（1）住宅の所有形態と対応行動との関係

地震発生直後〜 1 ヶ月後程度における緊急避難先についてみてみ 


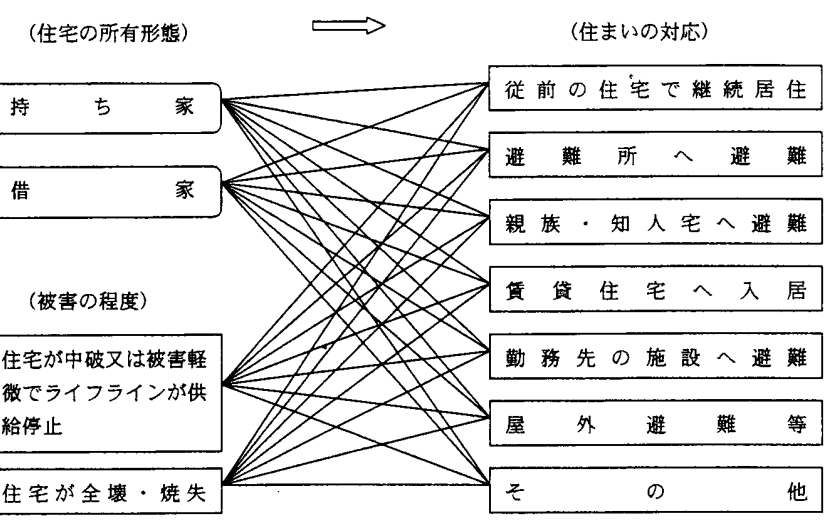

（a）地震発生直後〜 1 力月後の避難先の確保対応

(住宅の所有形態) $\Longrightarrow$

（住まいの対応）

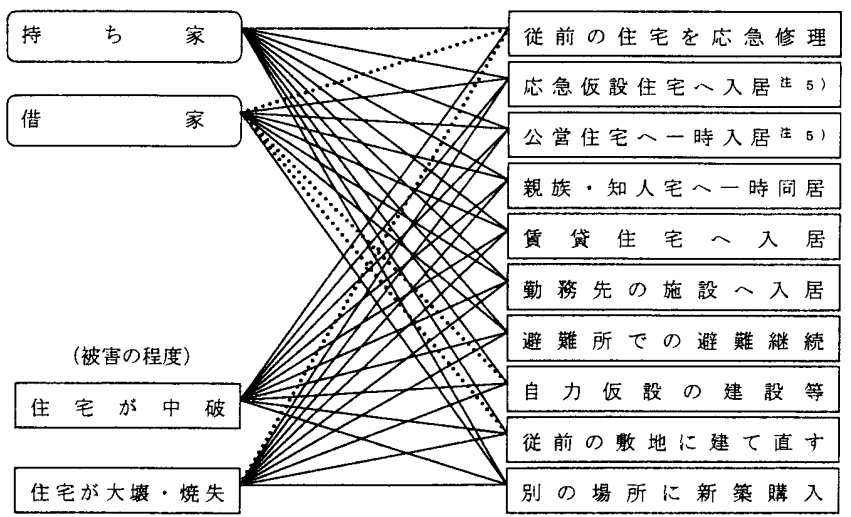

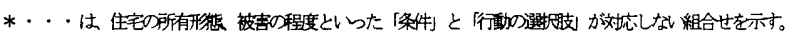

(b) 地震発生直後 1 力月後程度の応急住宅確保対応

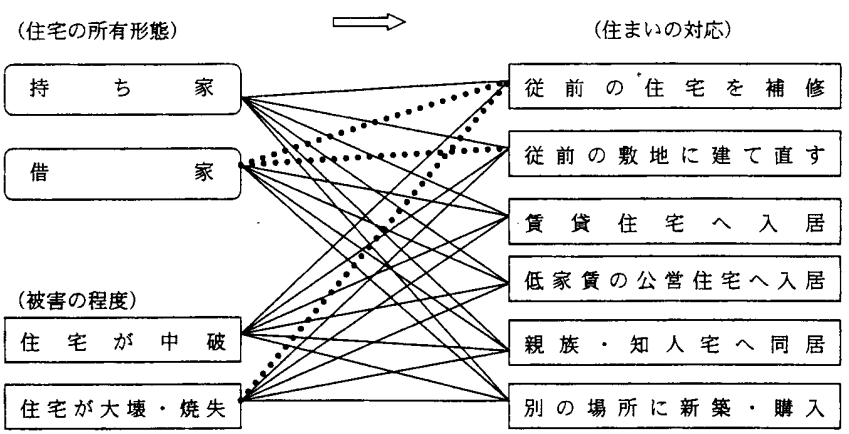

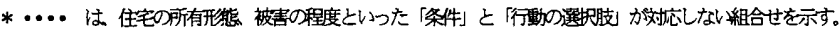

(c) 地震発生 1 年後以降の恒久住宅確保対応

図 1 地震発生後の各時間7エ亿ズ 毎の住まいの確保対応の選択肢の設定

ると、まず、「住宅の被害が中破、軽微・無被害で継続居住が可能で あるが上水道、電気等のライフラインの供給が停止」した場合の対 态では、「持ち家世帯」が「借家世帯」に比べ、従前の住宅に住み続 ける割合が高く、借家のカが親族・知人宅、勤務先の施設に避難す る割合が高くなっている。注6)注7)「住宅が大破・焼失し、居住が困 難」となった場合も、「借家世帯」の方が親族・知人宅、勤務先の施 設に避難する割合がやや高くなっているが、「持ち家世帯」との間に 大きな差は見られなかった。注6) 注7)（表 1,2 参照）

地震発生後 1 ケ月 1 年後程度における忘急住宅の確保対応、地
震発生後 1 年以降の恒久住宅の確保対応については、「持ち家世带」 の場合と「借家世帯」の場合で対応の選択肢自体が異なるため、両 者の統計的な差異を見ることは意味がないが、両者の対応行動は大 きく異なる。

応急住宅の確保対応では、「住宅の被害が中破程度で、応急修理を 施せば居住可能」という状況の場合は、「持ち家世帯」の8割が応急 修理をして従前の住宅に住み続けると答え、応急仮設住宅への入居 を希望する世帯は約 7\%と僅かではあるが、需要が存在する。一方、 「借家世帯」では、応急仮設住宅、公営住宅への一時入居といった 行政が提供する态急住宅への入居を希望する世帯がそれぞれ約 3 割 を占めている。注5)「住宅が大破・焼失し修理が困難」となった場合、

「借家世帯」では、中破の際の対応とほぼ同様であるが、「持ち家世 帯」については、忘急仮設住宅への入居を希望する世帯が中破の際 に比べ大幅に增え、全体の約 36\%を占めている。また、この時点で 早期に住宅を元の敷地に立て直寸という回答が約 $15 \%$ を占め、選択 肢の中で 3 番目に高い值を示している。(表 3,4 参照)

地震発生後 1 年後以降の恒久住宅の確保対応で注、「住宅の被害 が中破程度で、補修を施せば居住可能」という状況の場合は、「持ち 家世帯」の77\%が補修をして従前の住宅に住み続けると答え、次い で同じ敷地に立て直すという回答が約 $14 \%$ と多い。「借家世帯」で は、低家貨の公営住宅への入居を希望する世帯が全体の5割を上回 り最も多く、次いで、一般の賃貸住宅への入居が $28 \%$ と多くなって いる。「住宅が大破・焼失し補修が困難」となった場合、「借家世帯」 では、中破の際の対応とほぼ同様であるが、「持ち家世帯」について は、住宅を元の敷地に立て直すといら回答が約 $68 \%$ を占最も多い 一方、低家貨の公営住宅への入居を希望する世帯が $17 \%$ と 2 番目に 多くなっている。(表 5,6 参照)

こうした、被災後の住まいの確保に関する対応の違いは、時系列 の各段階での住宅確保対応の決定の際に優先する要因が、持ち家世 帯と借家世帯とでは、大きく異なっている注のことに起因していると 考えられる。表 7,8 は、住宅復興対応の決定に当たっての優先要因 を住宅の所有形態別に示したものであるが、「持ち家世帯」は、従前 の住宅からの近さを最も優先する世带が圧倒的に多く5割程度を占 めている。「借家世帯」で注、住居にかかる費用の安さ、通勤の便利 さ等を優先する世帯が多く、従前の住宅からの近さを最も優先する 世帯は、約 18\%に止まっている。注つ

（2）世帯収入と対応行動との関係

本調査では、持ち家世帯 905 世帯、借家世帯 131 世帯をさらに世 帯年収階層により区分しクロス集計を行った。持ち家では、年収階 層を 400 万円未満（325 世帯）、400 万円以上 1000 万円末満（401世 帯)、1000 万円以上 (317 世帯) の3つに分類し、借家では、十分な 票数が得られていないため年収階層を 400 万円未満注 8 ）(63 世帯）、 400 万円以上（61 世帯）の2 つに分類した。

地震発生直後〜 1 ケ月後程度における、「持ち家世帯」の緊急避難 先についてみてみると、「住宅の被害が中破、軽微・無被害で継続居 住が可能であるが上水道、電気等のライフラインの供給が停止」し た場合の対応では、世帯年収が高い方が、従前の住宅に住み続ける 割合が高く、避難所に避難する率は低い。また絶対数は小さいが、 貨貸住宅に入居する比率が相対的に高くなっている。一方世帯年収 400 万円未満の世帯では、避難所に避難する割合が高く約 4 割を占 
めている。注6)注》（表 9 参照）

地震発生後 1 ケ月 1 年後程度における「持ち家世帯」の応急住 宅の確保対応では、「住宅が大破・焼失し修理が困難」となった場合、 世帯年収の低い世帯の方が、応急仮設住宅一の入居を希望する割合 が相対的に高く、年収 400 万円未満の世帯では約 $43 \%$ を占めている。 一方、年収の高い世帯の方が、勤務先の施設、賃貸住宅への入居、 従前の敷地に立て直す世帯の割合が年収の低い世帯に比べ高くなっ ている。注6)注7) (表 10 参照)

同時期における「借家世帯」について見てみると、「住宅が大破・ 焼失」した場合、世帯年収が低い方が、応急仮設住宅、公営住宅へ の一時入居といった行政が提供する応急住宅への入居を希望する世 帯の比率が高く、世帯年収の高い方が、勤務先の施設への入居世帯の 比率が高くなっている。注6)注7) (表 11 参照)

地震発生後 1 年後以降の「持ち家世帯」の恒久住宅の確保対応で は、「住宅が大破・焼失し補修が困難」となった場合、絶対数として は、同一敷地に立て直すという対応がどの世帯年収階層でも最も多 いが、年収階層毎の違いを見ると、世带年収が低い方が、低家貨の 公営住宅一の入居を希望する世帯、親族・知人宅一恒久的に住むと いう世帯の比率が高く、従前の敷地に立て直す、別の居場所に新築・ 購入するといった世帯の比率が低くなっている。一方、世帯年収が 高い方が、同一敷地に立て直す、別の居場所に新築・購入するとい う世帯の比率が高く、低家貨の公営住宅への入居を希望するという 世帯の比率が低くなっている。注6) 注7)（表 12 参照）

同時期にお梳る「借家世帯」について見てみると、「住宅が大破・ 焼失」した場合、世帯年収が低い方が、低家賃の公営住宅への入居 を希望する世帯の比率が高く、世帯年収の高い方が、一般の賃貸住宅 への入居世帯の比率が高くなっている。注6)注》（表 13 参照）

こうした、被災後の住まいの確保に関する対応の違いは、時系列 の各段階で住宅確保対応を決定する際に優先する要因が、世帯年収 別に異なっている注 6)ことに起因していると考えられる。表 14,15 は、住宅復興対応の決定に当たっての優先要因を世帯の年収区分別 に示したものであるが、世帯年収が低い方が、居住にかかる費用の 安さを最も優先する世帯の比率が高く、世帯年収が高い方が、通勤 の便利さを最も優先している世帯の比率が高くなっている。注》

（3）世帯主の年路と対応行動之の関係

本調查では、阪神・淡路大震災等の事例において特に高㱓者層に 対する住宅復興支援が問題となっていることから、持ち家世帯 905 世帯、借家世帯 131 世帯をさらに世帯主の年齢により区分しクロス 集計を行った。世帯主の年齢階層を 65 歳以上 (持ち家: 439 世帯 借 家：44 世帯）、50 歳以上 65 歳未満（持ち家：327 世帯 借家：36 世 帯)、50 歳未満（持ち家：135 世帯 借家 : 51 世帯）の3つに分類し た。

地震発生直後〜 1 ヶ月後程度における、「持ち家世帯」の緊急避難 先についてみてみると、「住宅が大破・焼失し、居住が困難」となっ た場合、「世帯主の年齢が高い」方が、避難所に避難する割合が相対 的に高く、逆に貸貸住宅に入居寸る比率が他の階層に比べて低くな っている。「世帯主の年齢が 50 歳未満の世帯」では、勤務先の施設、 親族・知人宅一避難する割合が他の階層に比心゙高く、避難所に避難 する比率が相対的に低い。「50 歳以上 65 歳未満の世帯」では、賃貸 住宅への入居の割合が他の階層に比べ高くなっている。注6) 注7) (表
16 参照)

地震発生後 1 ケ月〜 1 年後程度における「持ち家世帯」の応急住 宅の確保対応では、「住宅が大破・焼失し修理が困難」となった場合、 世帯主の年齢が「65 歳以上の世帯」における応急仮設住宅への入居 を希望する割合が他の階層に比べに高く、逆に貨貸住宅への入居、 公営住宅一の一時入居の比率は低くなっている。一方、世帯主の年 齢が「50 歳未満の世帯」では、勤務先の施設、貨貸住宅への入居、 従前の敷地に立て直す世帯の割合が年収の低い世帯に比べ高く、逆 に応急仮設住宅への入居を希望する世帯の比率は低くなっている。 注6) 注7) (表 17 参照)

地震発生後 1 年後以降の「借家世帯」の恒久住宅の確保対応では、 「住宅が中破」の場合、世帯主の年㱓が「65歳以上の世帯」では、 低家貨の公営住宅への入居を希望する割合が他の階層に比べ高く、

「50 歳未満の世帯」の倍以上の割合となっている。一方「50 歳未満 の世帯」では、貨貸住宅への入居の割合が他に比心゙高くなっている。 注6) 注7) (表 18 参照)

図 2 は、世帯主の年齢階層と各段階での住まいの復興対応に関す るクロス集計結果に基づき、各カテゴリーの類似性を見るために行 ったコレスポンデンス分析の結果を示した図である。注9)

地震直後〜1 ケ月後の避難先（持ち家で住宅が大破した場合）に ついて見てみると、「世帯主の年齢が 65 歳以上の世帯」は、避難所 への避難、屋外避難といった選択肢に近く、「50 歳以上 65 歳未満の 世帯」は貨貸住宅、50 歳未満の世帯は勤務先の施設、親族・知人宅 といった選択肢に近いことがわかる。

地震発生後 1 ケ月〜1 年後の念急住宅対応（持ち家で住宅が大破 した場合)について見てみると、「世帯主の年齢が 65 歳以上の世帯」 は、応急仮設住宅への入居、避難所への避難生活の継続といった選 択肢に近く、「50 歳以上 65 歳未満の世帯」は、同一敷地に立て直す、 別の場所に新築・購入、公営住宅への一時入居といった選択肢、「50 歳未満の世帯」は勤務先の施設、賃貸住宅への入居といった選択肢 にそれぞれ近いことがわかる。

また、地震発生 1 年後以降の恒久住宅対応（持ち家で住宅が大破 した場合)について見てみると、「世帯主の年跉が 65 歳以上の世帯」 は、低家貨の公営住宅への入居、親族 - 知人宅への同居といった選 択肢に近く、「50 歳以上 65 歳未満の世帯」は、同一敷地に立て直す、 別の場所に新築・購入といった選択肢、「50 歳未満の世帯」は貨貸 住宅への入居といった選択肢にそれぞれ近いことがわかる。

こうした、被災後の住まいの確保に関する対応の違いは、時系列 の各段階での住宅確保対応の決定の際に優先する要因が、世帯主の 年龄階層別に異なっている注 6)ことに起因していると考えられる。 表 19,20は、住宅復興対応の決定に当たっての優先要因を世帯主の 年龄階層別に示したものであるが、世帯主の年齢が高い方が、従前 の住宅からの近さ、面倒を見ているあるいは見てもらう親族宅への 近さを最も優先する世帯の比率が高く、世帯主の年齢が低い方が、 通勤、通学の便利さを最も優先している世帯の比率が高くなってい る。注7)

\section{5. 供給側の制約条件による需要の変化}

表 21 は、応急仮設住宅への入居を希望する人の内、従前の居住地 からの距離の限界を $2 \sim 3 \mathrm{~km}$ 以内とする人が「借家世帯」で $69 \%$ 、 
表 1 住宅の所有形態別の避難先（住宅が中破又はライフラインの供給停止）＊**注6)

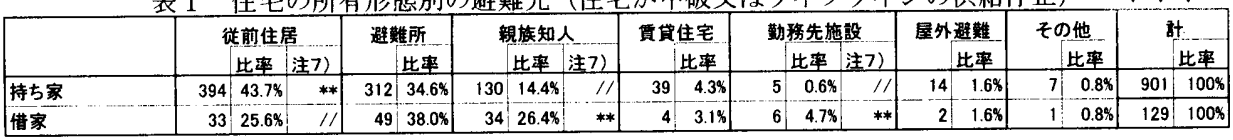

注: 表題横及び表中の*印、印に つては、注 6 及び注 7 を参照

表 2 住宅の所有形態別の避難先（住宅が大破・焼失の場合（住居不可能））*注6）

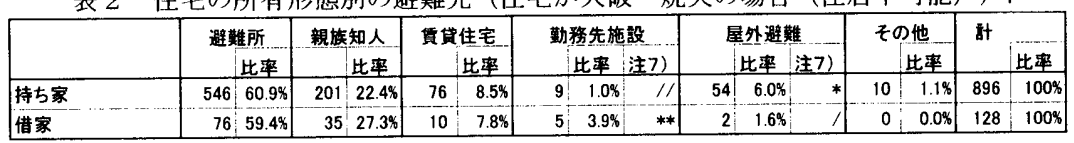

表 3 住宅の所有形態別の応急住宅確保対応（住宅が中破の場合（応急修理により住居可能））

\begin{tabular}{|c|c|c|c|c|c|c|c|c|c|c|c|c|c|}
\hline & $\begin{array}{r}\text { 厄急䇾理 } \\
\text { 比率 }\end{array}$ & $\begin{array}{r}\text { 応急仮設 } \\
\text { 比率 }\end{array}$ & $\begin{array}{r}\text { 公営一䁃 } \\
\text { 比率 }\end{array}$ & $\begin{array}{r}\text { 避難所 } \\
\text { 比率 }\end{array}$ & $\begin{array}{r}\text { 勤務先施設 } \\
\text { 比率 }\end{array}$ & $\begin{array}{r}\text { 親族·知人宝 } \\
\text { 比舞 }\end{array}$ & $\begin{array}{r}\text { 頁售住宝 } \\
\text { 比率 }\end{array}$ & $\begin{array}{r}\text { 自力饭貶 } \\
\text { 比率 }\end{array}$ & $\begin{array}{r}\text { 建て直し } \\
\text { 此率 }\end{array}$ & $\begin{array}{r}\text { 新築購入 } \\
\text { 比索 }\end{array}$ & $\begin{array}{c}\text { その他 } \\
\text { 比率 }\end{array}$ & ît & 比率 \\
\hline 持ち家 & \begin{tabular}{|l|l|}
714 & 80.08 \\
\end{tabular} & \begin{tabular}{|l|l|}
63 & $7.1 \%$ \\
\end{tabular} & \begin{tabular}{l|l|}
24 & $2.7 \%$ \\
\end{tabular} & $2 \quad 0.2 \%$ & \begin{tabular}{|l|l|}
1 & $0.18 \%$ \\
\end{tabular} & \begin{tabular}{|l|l|}
37 & $4.1 \%$ \\
\end{tabular} & $\begin{array}{lll}17 & 1.98 \\
\end{array}$ & \begin{tabular}{|l|l|}
10 & $1.1 \%$ \\
\end{tabular} & \begin{tabular}{|l|l|}
20 & 2.28 \\
\end{tabular} & \begin{tabular}{|l|l|}
4 & $0.4 \%$ \\
\end{tabular} & $\begin{array}{ll}0.0 \% \\
\end{array}$ & 892 & $100 \%$ \\
\hline 借家 & $0.0 \%$ & $\begin{array}{ll}38 & 30.4 \%\end{array}$ & $37,29.6 \%$ & $0.0 \%$ & $9.6 \%$ & $22 \quad 17.6 \%$ & 13: $10.4 x$ & 2.48 & $0.0 \%$ & $0.0 \%$ & $0.0 \%$ & 125 & $100 \%$ \\
\hline
\end{tabular}

表 4 住宅の所有形態別の念急住宅確保対応（住宅が大破・焼失の場合（修理不能））

\begin{tabular}{|c|c|c|c|c|c|c|c|c|c|c|c|}
\hline & $\begin{array}{r}\text { 流急仮設 } \\
\text { 比率 } \\
\end{array}$ & $\begin{array}{r}\text { 公蒙一時 } \\
\text { 比率 }\end{array}$ & $\begin{array}{r}\text { 避嚾所 } \\
\text { 非案 } \\
\end{array}$ & $\begin{array}{c}\text { 勤務先施設 } \\
\text { 比率 } \\
\end{array}$ & $\begin{array}{c}\text { 親族知人 } \\
\text { 比事 } \\
\end{array}$ & $\begin{array}{r}\text { 垻貸住宅 } \\
\text { 比率 } \\
\end{array}$ & $\begin{array}{r}\text { 自力仮骰 } \\
\text { 比雍 } \\
\end{array}$ & $\begin{array}{r}\text { 建て直し } \\
\text { 比無 } \\
\end{array}$ & $\begin{array}{c}\text { 新樂購入 } \\
\text { 比率 } \\
\end{array}$ & $\begin{array}{c}\text { その他 } \\
\text { 比率 }\end{array}$ & 站 \\
\hline 持ち家 & $\begin{array}{lll}312 & 35.9 \% \\
\end{array}$ & $\begin{array}{ll}159 & 18.38 \\
\end{array}$ & \begin{tabular}{ll|}
4 & $0.5 \%$ \\
\end{tabular} & $\begin{array}{rr}8 & 0.9 \% \\
\end{array}$ & $107 \quad 12.38$ & $\begin{array}{rr}53 & 6.18\end{array}$ & $\begin{array}{ll}86 & 9.9 \%\end{array}$ & $134 \quad 15.48$ & $\begin{array}{ll}5 & 0.6 \% \\
\end{array}$ & $\begin{array}{ll}2 & 0.28\end{array}$ & $870 \quad 100 \%$ \\
\hline 惜家 & $\begin{array}{lll}38 & 30.2 \%\end{array}$ & $\begin{array}{lll}38 & 30.28\end{array}$ & $0.0 \%$ & 7.18 & $\begin{array}{ll}26 & 20.68 \\
\end{array}$ & $9.5 \%$ & $1.6 \%$ & $\begin{array}{lll}0 & 0.0 \%\end{array}$ & $1,0.8 \%$ & $0.0 \%$ & $100 \%$ \\
\hline
\end{tabular}

表 5 住宅の所有形態別の恒久住宅確保対応（住宅が中破の場合（補修により恒久的に居住可能））

\begin{tabular}{|c|c|c|c|c|c|c|c|c|c|c|c|c|c|c|c|c|}
\hline \multirow[b]{2}{*}{ 持ち家 } & \multicolumn{2}{|c|}{$\begin{array}{c}\text { 補修 } \\
\text { 比花 }\end{array}$} & \multicolumn{2}{|c|}{$\begin{array}{r}\text { 建て直L } \\
\text { 此衰 } \\
\end{array}$} & \multicolumn{2}{|c|}{$\begin{array}{c}\text { 筫貸住宅 } \\
\text { 比整 } \\
\end{array}$} & \multicolumn{2}{|c|}{\begin{tabular}{|c|} 
低家質公黨住宅 \\
比毫 \\
\end{tabular}} & \multicolumn{2}{|c|}{ 親族-知人宅 } & \multicolumn{2}{|c|}{$\begin{array}{r}\text { 新築睡入 } \\
\text { 比往 }\end{array}$} & \multicolumn{2}{|c|}{$\begin{array}{l}\text { その他 } \\
\text { 比率 }\end{array}$} & \multicolumn{2}{|c|}{$\begin{array}{l}\text { 部 } \\
\text { 比率 }\end{array}$} \\
\hline & 684 & $77.0 \%$ & 127 & $14.3 \%$ & 12 & $1.4 \%$ & 26 & $2.9 \%$ & 16 & $1.8 \%$ & 21 & $2.4 \%$ & 2 & $0.2 \%$ & 888 & $100 \%$ \\
\hline 借家 & 0 & $0.0 \%$ & 0 & $0.0 \%$ & 33 & $28.0 \%$ & 61 & $51.7 \%$ & 14 & $11.9 \%$ & 6 & $5.1 \%$ & 4 & $3.4 \%$ & 118 & $100 \%$ \\
\hline
\end{tabular}

表 6 住宅の所有形態別の恒久住宅確保対応（住宅が大破・焼失の場合（補修不可能））

\begin{tabular}{|c|c|c|c|c|c|c|c|c|c|c|c|c|c|c|}
\hline & \multicolumn{2}{|c|}{$\begin{array}{c}\text { 建て直L } \\
\text { 比搽 } \\
\end{array}$} & \multicolumn{2}{|c|}{$\begin{array}{r}\text { 貫贷住宅 } \\
\text { 比毫 }\end{array}$} & \multicolumn{2}{|c|}{$\begin{array}{c}\text { 低家筫公㗬住宝 } \\
\text { 比率 }\end{array}$} & \multicolumn{2}{|c|}{$\begin{array}{c}\text { 漞疾-知人宝 } \\
\text { 比事 }\end{array}$} & \multicolumn{2}{|c|}{$\begin{array}{r}\text { 新案購入 } \\
\text { 比率 }\end{array}$} & \multicolumn{2}{|c|}{$\begin{aligned} \text { その他 } \\
\text { 比率 } \\
\end{aligned}$} & \multicolumn{2}{|c|}{$\begin{array}{c}\text { 部 } \\
\text { 此率 } \\
\end{array}$} \\
\hline 持ち & 593 & $68.2 \%$ & 34 & $3.9 \%$ & 148 & $17.0 \%$ & 53 & $6.1 \%$ & 39 & $4.5 \%$ & 2 & $0.2 \%$ & 869 & $100 \%$ \\
\hline 借家 & & $0.0 \%$ & 33 & $27.3 \%$ & 65 & 53.78 & 15 & $12.4 \%$ & 6 & $5.0 \%$ & 2 & $1.7 \%$ & 121 & $100 \%$ \\
\hline
\end{tabular}

表 7 住宅の所有形態別の対応決定の優先要因（地震発生後 1 个月 1 年後程度の応急住宅確保の際に優先する要因）***注 6 ）

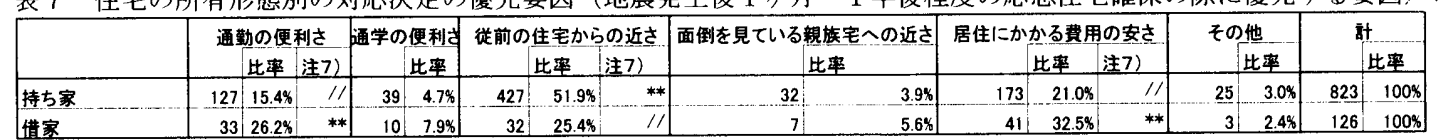

表 8 住宅の所有形態別の対応決定優先要因（地震発生後 1 年後以降の恒久住宅確保の際に優先する要因）****社 6 )

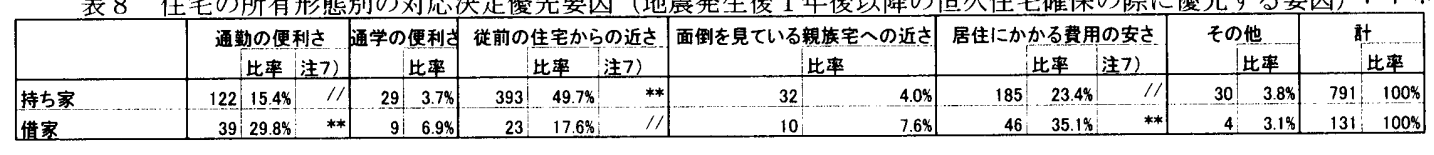

表 9 世帯年収別の避難先（持ち家/住宅が中破又はライフラインの供給停止の場合）＊*注6）

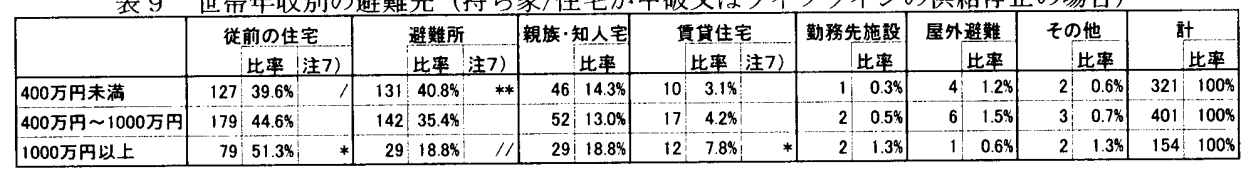

表10 世帯年収別の応急住宅確保対応（持ち家/住宅が大破・焼失の場合（修理不可能））

$* * *$ 注 6 )

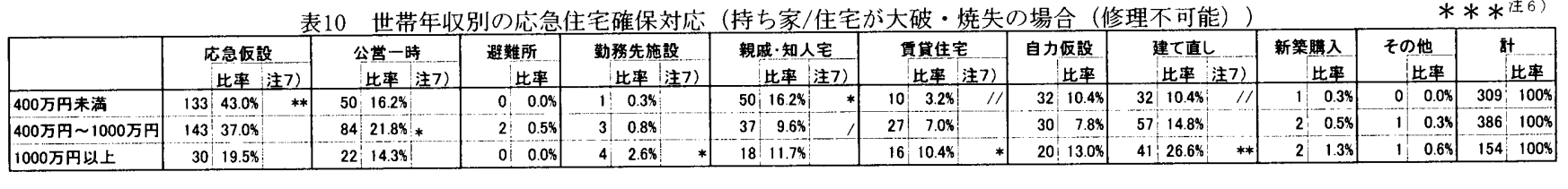

表11 世帯年収別の応急住宅確保対応（借家/住宅が大破・焼失の場合（修理不能））

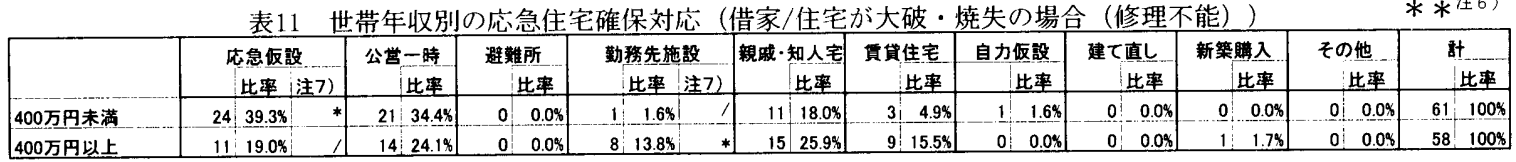

表12世帯年収別の恒久住宅確保対応（持ち家/住宅が大破・焼失の場合 (補修不能)）***社6)

\begin{tabular}{|c|c|c|c|c|c|c|c|c|c|c|c|c|c|c|c|c|c|}
\hline & \multicolumn{3}{|c|}{ 建て直し } & \multicolumn{2}{|c|}{ 賈貨住宅 } & \multicolumn{3}{|c|}{ 低家筫公棠住宅 } & \multicolumn{3}{|c|}{ 親盛-知人宅 } & \multicolumn{3}{|c|}{ 新䛶睡入 } & \multirow{2}{*}{ その他 } & \multirow[t]{2}{*}{ 計 } & \multirow{2}{*}{ 比谹 } \\
\hline & & 比率 & 注7) & & 比衰 & & 比事 & 注7) & & 比率 & 注7) & & 比率 & 注7) & & & \\
\hline 400万円末満 & 175 & $57.0 \%$ & 11 & 13 & $4.2 \%$ & 83 & $27.0 \%$ & $* *$ & 32 & $10.4 \%$ & $* *$ & 4 & $1.3 \%$ & 11 & $0 \quad 0.0 \%$ & 307 & $100 \%$ \\
\hline 400 万円 1000万列 & 279 & 71.28 & & 17 & $4.3 \%$ & 60 & $15.3 \%$ & & 15 & $3.8 \%$ & & 20 & $5.1 \%$ & & $0.3 \%$ & 392 & $100 \%$ \\
\hline 400 万中以上 & 126 & $840 \%$ & ** & 2 & $1.3 \%$ & 3 & $2.0 \%$ & 11 & 4 & $2.7 \%$ & & 14 & $9.3 \%$ & $* *$ & $0.7 \%$ & 150 & $100 \%$ \\
\hline
\end{tabular}

表13 世帯年収別の恒久住宅確保対応（借家/住宅が大破·焼失の場合））＊注6)

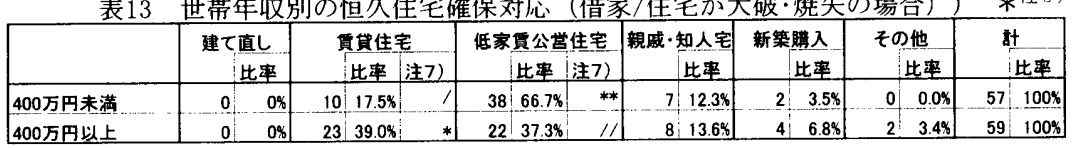


表14 世帯年収別の対応決定の優先要因（地震発生後1ヶ月〜1年後程度の忘急住宅確保の際に優先する要因）***注 6)

\begin{tabular}{|c|c|c|c|c|c|c|c|}
\hline & 通勤の便利さ & 通学の便利さ & 従前の住宅からの近さ & 面倒を見ている视矮宅への近さ & 居住にかかる員用の安さ & その地 & \\
\hline & 此率 注7) & 比率 注72 & 比事 & \begin{tabular}{|l|l|} 
& 比垔 \\
\end{tabular} & $\begin{array}{|ll|} & \text { 比率 } \\
\end{array}$ & 此率 & 比率 \\
\hline 20万円未渵 & $\begin{array}{ll}28 & 7.6 \% \\
\end{array}$ & $\begin{array}{lll}10 & 2.78 & 11\end{array}$ & $46.5 \$$ & 18 & $130 \quad 35.38 \quad * *$ & $11 \quad 3.0 \%$ & $368: 1$ \\
\hline 400万円 万 1000万円 & $80 \quad 18.78$. & 32 & 215 & $40 \%$ & 16.98 & 2.68 & \begin{tabular}{l|l}
$427 \quad 100 x$ \\
\end{tabular} \\
\hline 1000万円以上 & 51: $34.2 \%:$ & 6. 4.08 : & $48.3 \%$ & 2.78 & $11 \quad 7.48$ i $_{1}^{1}$ & $5.3 .4 \%$ & $\begin{array}{ll}149 & 1008 \\
\end{array}$ \\
\hline
\end{tabular}

表15 世帯年収別の対応決定の優先要因（地震発生後 1 年後以降の恒久住宅確保の際に優先士る要因）***注6)

\begin{tabular}{|c|c|c|c|c|c|c|c|}
\hline & $\begin{array}{r}\text { 通勤の便利さ } \\
\text { 比率：注7) } \\
\end{array}$ & $\begin{aligned} \text { 通学の便利さ } \\
\text { 比整 注7) } \\
\end{aligned}$ & $\begin{array}{c}\text { 従前の住宅からの近さ } \\
\text { 比率 }\end{array}$ & 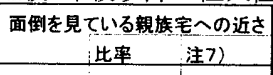 & $\begin{array}{c}\text { 居住にかかる費用の安さ } \\
\text { 比㳯 注7) } \\
\end{array}$ & $\begin{array}{c}\text { その他 } \\
\text { 比谹 } \\
\end{array}$ & $\begin{array}{l}\text { 站 } \\
\text { 比率 } \\
\end{array}$ \\
\hline 400万五末淦 & $22 \quad 6.9 \% \quad / /$ & $5 \quad 168 \quad 11$ & $134 \quad 42.08$ & $\begin{array}{ll}17 & 538\end{array}$ & $40.8 \% \quad * *$ & $11 \quad 3.48$ & $319 \quad 100 \%$ \\
\hline 400万万円 1000万同 & 801948 & $28 \quad 6.8 \% \quad * *$ & 48.48 & 5.18 & 16.78 & 3.68 & $413 \quad 100 \%$ \\
\hline 1000 万巴以上 & $50 \quad 35.2 \%$ & $5 \quad 3.5 \%$ & 47.98 & $0.0 \%$ & $9.2 \%$ & $4.2 \%$ & 142 \\
\hline
\end{tabular}

表16 世帯主の年龄別避難先（持ち家/住宅が大破・焼失の場合（居住不能））***注6)

\begin{tabular}{|c|c|c|c|c|c|c|c|c|c|}
\hline & & 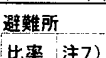 & 視族-知人宅 & 䨘黛住宅 & 勤務先施粗 & 屋外避鹳 & その他 & & it \\
\hline 50貲未渵 & 68 & $50.4 \%$ & $43,31.9 \% \quad * *$ & 128.98 & $5 \quad 3.78$ & 4.48 & if $0.7 \%$ & 135 & $100 \%$ \\
\hline 50 歳以上 65 感未满 & 196 & $60.1 \%$ & $67 \quad 20.6 \%$ & \begin{tabular}{l|l|}
44 & $13.5 \%$ \\
\end{tabular} & $00.0 \%$ & $4.9 \%$ & \begin{tabular}{l|l}
3 & $0.9 \%$ \\
\end{tabular} & 326 & $100 \%$ \\
\hline 65 嵅以上 & 280 & $65.0 \%$ & $90,20.9 \%$ & $20.4 .6 \%$ & 4. $0.9 \%$ & $7.2 \%$ & $\begin{array}{ll}6 & 1.48\end{array}$ & 431. & $100 \%$ \\
\hline
\end{tabular}

表17 世带主の年齢別の応急住宅確保対応（持ち家/住宅が大破·焼失の場合（修理不能））

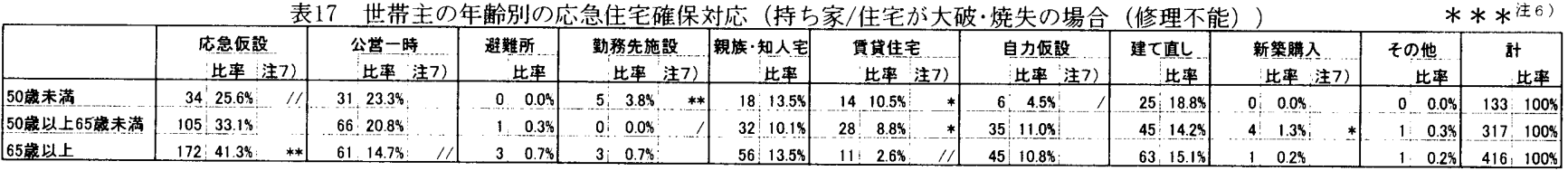

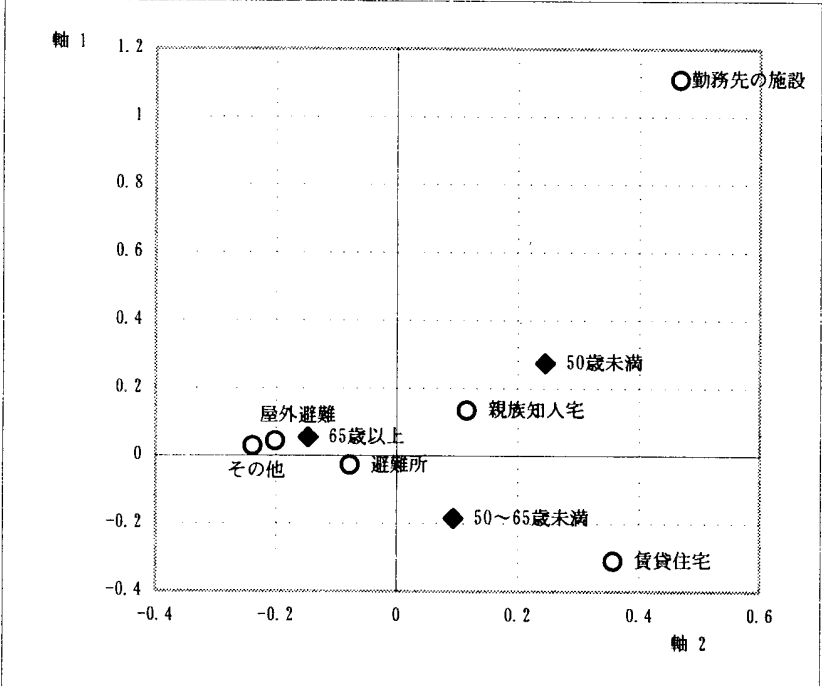

（a）地震発生直後～ 1 力月後の避難先の確保対応（持ち家）

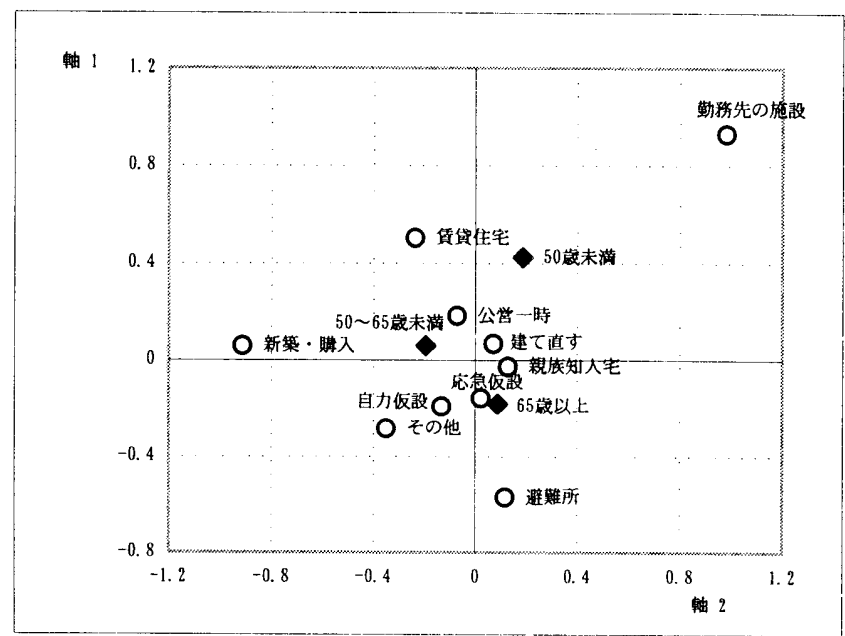

（b）地震発生 1 ケ月～ 1 年後程度の応急住宅確保対応（持ち家）
表18 世帯主の年踰別の恒久住宅確保対店

*注6) (借家/住宅が中破の場合)

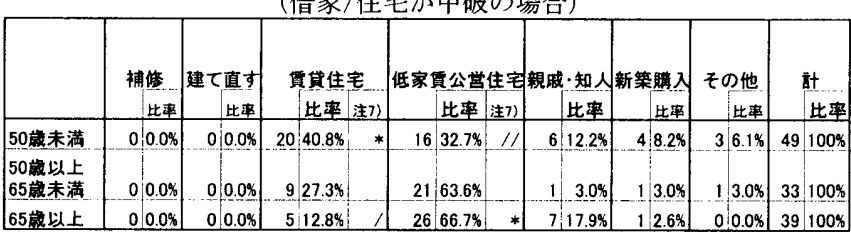

表19 世帯主の年齢別の対応決定の優先要因 $* * *$ 注6 ) (地震発生後 1 ヶ月〜1年後程度の応急住宅確保の際に優先す万要因)

\begin{tabular}{|c|c|c|c|c|c|c|c|c|c|c|c|c|c|}
\hline & \multicolumn{2}{|c|}{ 通勤の便利さ } & \multicolumn{3}{|c|}{ 通学の便利さ } & \multicolumn{2}{|c|}{$\begin{array}{c}\text { 従前の住宅 } \\
\text { からの近さ }\end{array}$} & \multicolumn{2}{|c|}{$\begin{array}{c}\text { 面倒を見て } \\
\text { いる親族宅 } \\
\text { への近さ }\end{array}$} & \begin{tabular}{|c|} 
居住にか \\
掏用 \\
の安さ
\end{tabular} & その地 & \multirow{2}{*}{\multicolumn{2}{|c|}{$\begin{array}{l}\text { 站 } \\
\text { 比事 }\end{array}$}} \\
\hline & 此率 & 洼7) & & 此事 & 注7) & 比建; & 注72 & 比率: & 洼72 & 比率 & 比搽 & & \\
\hline 50葴未満 & $4725.7 \%$ & $* *$ & 36 & $19.7 \%$ & ** & $6233.9 \%$ & II & 3) 1.68 . & & $3217.5 \%$ & $\begin{array}{ll}3.6 \% \\
3.6 \%\end{array}$ & 183 & $100 \%$ \\
\hline $\begin{array}{l}\text { 50㦱以上 } \\
65 \text { 歳未満 }\end{array}$ & $9125.6 \%$ & $* *$ & 4 & 1.18 & 1 & 164.46 .18 & & $2.5 \%$ & & $78.21 .9 \%$ & $2.8 \%$ & 356 & $100 \%$ \\
\hline 65宠以上 & \begin{tabular}{l|l}
24 & $5.7 \%$ \\
\end{tabular} & $1 /$ & 10 & $2.4 \% !$ & 11 & 234 .55.8\% & $* *$ & \begin{tabular}{l|l|}
29 & $6.9 \%$ \\
\end{tabular} & $* *$ & $105|25.18|$ & \begin{tabular}{l|l}
17 & $4.1 \%$ \\
\end{tabular} & 419 & $100 \%$ \\
\hline
\end{tabular}

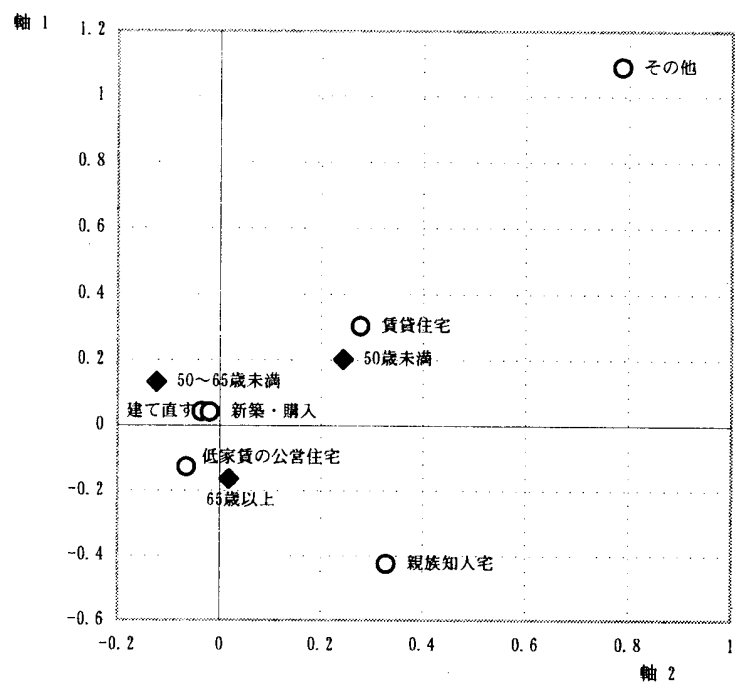

（c）地震発生 1 年後以降の恒久住宅確保対応（持ち家）

図 2 各カテゴリーの類似度 
表20 世帯主の年齢別の対応決定の優先要因 $* * *$ 注6) (地震発生後 1 年後以降の恒久住宅確保の際に優先する要因)

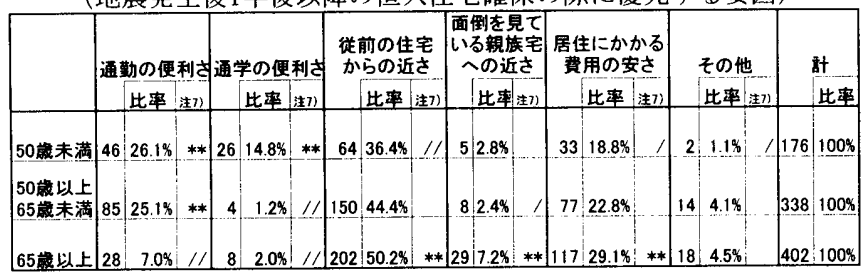

表21 応急仮設住宅選択世帯における従前の住宅からの限界距離 (住宅の所有形態別)

\begin{tabular}{|c|c|c|c|c|c|c|c|c|c|}
\hline & \multirow{2}{*}{\multicolumn{2}{|c|}{$\begin{array}{c}\text { 徉前の居住地から } \\
1 \mathrm{~km} \text { 的内 }\end{array}$}} & \multicolumn{2}{|c|}{ 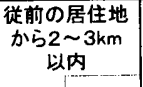 } & \multirow{2}{*}{\multicolumn{2}{|c|}{$\begin{array}{l}\text { 彷前の居住地 } \\
\text { と同し市町材 }\end{array}$}} & \multirow{2}{*}{ 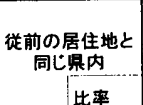 } & \multirow{2}{*}{\multicolumn{2}{|c|}{$\begin{array}{l}\text { st } \\
\text { 比率 }\end{array}$}} \\
\hline & & & & 比事 & & & & & \\
\hline & 191 & $47.8 \%$ & 102 & 25.54 & 99 & $24.8 \%$ & $\begin{array}{ll}8 & 2.08 \\
\end{array}$ & 400 & $100 \%$ \\
\hline 借家 & 36 & 44.48 & 20 & 24.76 & 25 & 30.98 & 0.08 & 81 & $100 \%$ \\
\hline
\end{tabular}

表22 低家賃の公営住宅選択世帯における従前住宅からの限界距離 (世帯主の年齢別)

\begin{tabular}{|c|c|c|c|c|c|c|c|c|}
\hline & $\begin{array}{l}\text { 従前の居住 } \\
1 \text { km以 }\end{array}$ & 地から & $\begin{array}{c}\text { 従媊の居住地 } \\
\text { 占22 } 2 \text { 以 } \\
\text { 以内 }\end{array}$ & 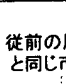 & 覻住地 & $\begin{array}{l}\text { 従前の居住地と } \\
\text { 同し照内 }\end{array}$ & & \\
\hline & 此 & & 比萍 & & 此事 & 比事 & & 比率 \\
\hline 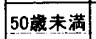 & 23 & 34.38 & $21 \quad 31.3 \%$ & 22 & $32.8 \%$ & $1 \quad 1.5 \%$ & 67 & $100 \%$ \\
\hline 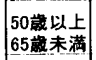 & 51 & $43.2 \%$ & $25.4 \%$ & 37 & $31.4 \%$ & $0 \quad 0.0 \%$ & 118 & \\
\hline 鹿以上 & 96 . & $54.2 \%$ & $16.4 \%$ & 48 & $27.1 \%$ & $\begin{array}{ll}4 & 2.3 \% \\
\end{array}$ & 177 & 1009 \\
\hline
\end{tabular}

「持ち家世帯」では73\%を占めており、これは、実際の念急仮設住 宅の立地場所に上っては、たとえ量的に需要を満たしていたとして も質的条件のミスマッチにより、多くの潜在需要に态えられないこ とになり、結果として顕在化する需要が減少するという現象が起こ りうることを示しているものである。

また、同様のことが低家貨の公営住宅の建設等についても言え、 低家貨の公営住宅への入居を希望寸る人の内、従前の居住地からの 距離の限界を $1 \mathrm{~km}$ 以内と寸る回答が「世帶主の年齢が 65 歳以上の 世帯」では約 $54 \%$ 、「50 歳以上 65 歳未満の世帯」でも約 $43 \%$ を占 めている。(表 22 参照)

\section{6.まとめ}

本研究では、地震災害からの住まいの復興対応は、地震発生後の 各段階において、「住宅の所有形態」「世带の年収区分」「世带主の 年齢」といった従前の世帯の属性及び住宅の被害の程度と媣く関わ っていることが明らかになった。

特に、行政が実施する住宅復興效策と直接的に結びついている、 (1)地震発生直後の避難先として避難所需要、(2)中期的な匛急住宅対 策としての応急仮設住宅需要、公営住宅への一時入居に関する需要、 (3)恒久住宅対策としての低家貨の公営住宅需要について、それぞれ、 世帯属性、住宅の被害の程度との関連を整理する。

(1)地震発生直後の避難先として避難所需要は、住宅が大破した場 合の方が避難所に行く割合は高いものの、中破又はライフラインの 供給停止の際との差は、(2)(3)に比べ大きくない。また、住宅の所有 形態別の差も小さい。一方、世帯年収別、世帯主の年齢別に見ると、 世帯年収の低い世帯、世帯主の年齢の高い世帯（相対的な社会的弱 者）の方が避難所へ行く比率は高い。

(2)中期的な応急住宅対策としての応急仮設住宅需要、公営住宅一 の一時入居に関する需要は以下のようになっている。まず応急仮設 住宅需要については、住宅が中破の場合は、持ち家世帯では応急修
理による居住の継続を望む比率が非常に高く、応急仮設住宅への入 居希望は、僅かであるが需要として存在している。一方、借家世帯 では、中破であっても大破した場合とほぼ同程度の高い割合で応急 仮設住宅への入居需要が存在している。注5)大破の場合は、持ち家世 帯の方が入居を希望する比率が借家世帯をやや上回っているが、有 意な差は認められない。一方、世帯年収別、世带主の年齢別に見る と、世帯年収の低い世帯、世帯主の年齢の高い世帯の方が応急仮設 住宅への入居を希望する比率は高い。

公営住宅への一時入居に関する需要については、借家世帯の方が 入居を希望する比率は高い。持ち家世帯では、応急仮設住宅と同様 に中破の場合の需要は非常に小さいが存在している。一方世帶年収 別、世帯主の年齢別に見ると、明確な関連性は認められないものの 両者とも中間層における比率が高くなっている。

(3)恒久住宅対策としての低家貨の公営住宅需要は、借家世帯の方 が入居を希望する比率は压倒的に高い。持ち家世带の場合、中破で は入居希望の比率は非常に低く、大破の場合も借家に比べ大きく下 回っている。一方、世帯年収別、世带主の年齢別に見万と、世带年 収の低い世帯、世帯主の年龄の高い世帯の方が低家賃の公営住宅一 の入居を希望する比率は高い。

本抽出調查によって得られた地域特性としての、居住世帯の属性 別、被害の程度別、住まいの復興の各フェイズ別の対応意向の把握 結果と、当該地域の世帯属性別の世帯数及び被害想定の結果として の住宅被害の程度別の世帯比率を用いることにより、当該地域にお いて想定される地震被害に対応した住宅復興対策需要の推計を行う ことが可能になる。8

表 23 には例として、標本調査の平均值を用いた、世帯属性と住宅 被害の程度別の各カテゴリーにおける、主な住宅対策別の希望世帯 比率のテーブルを示した。この值に、当該地域の世帯属性上住宅被 害程度別の各カテジリーの世帯数を掛け合わせ累計することにより、 住宅対策需要の推計を行う事が考えられる。ここでは、既存の公表 されている統計データからの推計を前提とし、世帯属性としては、 住宅の所有形意と世帯収入を採り上げた。注10)また、応急仮設住宅、 公営住宅への一時入居に関しては、住宅の被害程度が中破の世带に おける需要も含めた場合の值を示している注5)他、応急仮設住宅、低 家貨の公営住宅への入居については、「需要者が希望する立地場所 に関する条件」（従前の住宅からの距離）をすべて満たしている場合 の希望世帯比率を採用しているが、希望世帯比率のテーブルを入れ 替えることにより、これらの条件を変えた場合の需要量の推計を行 うことも可能となる。

本研究は、地震災害からの住宅復興対策に関し、まず各自治体の 供給側の制約条件を考慮する前の潜在的な需要を推計するために必 要となる世帯及び住宅の属性、住宅の被害の程度と被災後の住まい の復興対応上の関係を明らかにするとともに、復興住宅の建設場所 による需要内容の変化などを把握しておくことにより、地方公共団 体等が将来発生する地震に備えた復興対策の事前の検討・準備を行 う際、あるいは地震発生直後に迅速な復興計画策定のための対策需 要の把握を行う際に、上り地域の特性を反映した需要推計の実見に 資寸るものであると考えられる。注11)一方、本研究においては、震災 発生時の季節・気候等の条件の違いによる対応の違い等については 対象としておらず、今後の研究課題である。 
表23 世帯属性別、住宅被害程度別の住宅対策潜在需要推計のための原単位 ${ }^{*}$ (需要世帯比率)

\begin{tabular}{|c|c|c|c|c|c|c|c|c|c|}
\hline \multirow{3}{*}{$\begin{array}{l}\text { 住所 } \\
\text { 宅有 } \\
\text { 形 } \\
\text { の態 }\end{array}$} & \multirow{3}{*}{\begin{tabular}{l} 
住宅復興対応のフィーズ \\
\multicolumn{2}{c|}{ 住まいの復興対策 } \\
世帯年収】住宅被客の程度
\end{tabular}} & \multirow{2}{*}{\multicolumn{2}{|c|}{$\frac{\text { 緊急避難対応 }}{\text { 避難所への避難 }}$}} & \multicolumn{4}{|c|}{ 急住宅対危 } & \multirow{2}{*}{\multicolumn{2}{|c|}{$\begin{array}{c}\text { 恒久住宅対応 } \\
\text { 低家䨘の公咅住宅への入居 }\end{array}$}} \\
\hline & & & & \multicolumn{2}{|c|}{ 応急仮設住宅への入居 注4) } & \multicolumn{2}{|c|}{ 公営住宅への一時入居 注4) } & & \\
\hline & & 大破 & 中破等 ** & 大破 & 中破 & 大破 & 中破 & 大破 & 中破 \\
\hline 持 & 400 万円未渾 & 0.65 & 0.41 & 0.43 & 0.08 & 0.16 & 0.03 & 0.27 & 0.06 \\
\hline 5 & 400万円～1000万円 & 0.61 & 0.35 & 0.37 & 0.07 & 0.22 & 0.03 & 0.15 & 0.01 \\
\hline 家 & 1000 万网以上 & 0.50 & 0.19 & 0.20 & 0.05 & 0.14 & 0.01 & 0.02 & 0.00 \\
\hline 惜 & 400万月末満 & 0.71 & 0.45 & 0.39 & 0.37 & 0.34 & 0.37 & 0.67 & 0.65 \\
\hline 家 & 400万円以上 & 0.46 & 0.30 & 0.19 & 0.23 & 0.24 & 0.22 & 0.37 & 0.37 \\
\hline
\end{tabular}

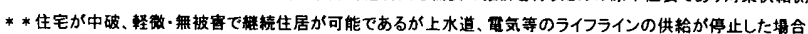

\section{謝辞}

本研究において実施した抽出調查は、静岡県の御協力を得、共同 で実施したものであり、記して謝意老表する次第である。

\section{参考文献}

1）静岡県 : 第 2 次地震被害想定結果, 1994.6

2）静岡県 : ふじの国住宅復興プラン, 1999.3

3）木村玲欧，他 3 名：阪神・淡路大震災後の被災者の移動とすまいの決定 に関する研究, 地域安全学会論文集, 地域安全学会, pp.93-102, 1999.11

4）木村玲欧，林春男，立木茂雄：阪神・淡路大霞災後の被災者の住まい再 建における決定とその規定因に関する研究, 地域安全学会論文集, 地域 安全学会, pp.15-24, 2000.11

5）福留邦洋，中林一樹：阪神・淡路大震災の被災市街地における住宅被害 と再建過程に関する分析一所有関係の視点から, 日本都市計画学会論文 集 No35, pp.403·408, 2000.11

6）平山洋介，木山幸介：被災市街地における住宅再建の実態分析一灘区南 東地区のケーススタディを通じて，日本建築学会論文集 No.512, pp.205·211, 1998.10

7）室崎益輝：阪神・淡路大震災における住宅再取得過程とその支援方策に 関する研究, 第 31 回日本都市計画学会学術研究論文集, 日本都市計画 学会, pp.799-804, 1996.11

8）池田浩敬, 中林一樹 : 震災復興対策の事前準備計画に関する方法論的研 究一住宅復興対策需要の事前推計一, 地域安全学会論文集, 地域安全学 会, pp.257-266, 2000.11

9）室崎益輝，流郷博史：阪神淡路大震災における市民の初期対応行動に関 する研究, 地域安全学会論文報告集, 地域安全学会, pp.206-212, 1996.11

10）兵庫県 : 応急仮設住宅入居者調查結果速報,1996.

11）兵庫県，(財） 21 世紀ひょうご創造協会：阪神·淡路大震災復興誌（第 1 巻) ,pp.226-242,1997.3

注

注 1 ）静岡県の地震被害措定においては、大破を住める見込みが非常に低 く、復旧が困難と考えられる建物、中破を復旧のためには大修理を 要すると考えられる建物と定義されている。また、同想定において は、大破・中破を合わせた被害の大きさを表す指標として、中破を 大破換算した「被害棟数」(=大破棟数＋中破棟数 $\times 1 / 2)$ 「被害率」 (被害棟数/建物棟数) と言う指標を用いている。ここでいう建物 被害率とは、上記定義を用いた。

注 2 ） 平成 7 年国勢調查報告のデータを用いた。

注 3 )世帯抽出には、電話艮データベースを用いた。

注 4 ）有効回収票数の市別の内訳は、静岡市 571 、浜松市 141 、清水市 206 、 沼津市 92 、富士市 25 、無回答 11 であった。無回答を除く各市の世 帯属性別構成比率には有意な差は見られなかった。

注 5 ）本来、応急仮設住宅の供与の対象となる者は「住家が全焼、全罗又 は流失した者」という条件が付されているが、阪神・淡路大霞災に おいては、被災地の混乱状態と緊急性の度合いを考慮し、柔軟な運 用がなされ、半壊を含め住家に被害を受けた被災者で入居を希望す る者全員に対象が拡大された。11そこで、本研究では、対策供給側 の制䄪条件を考慮する前の潜在需要の把握を目的として、住宅が中 破の場合についても応急仮設住宅の入居希望の割合を把握し需要
としてカウントすることとした。

注 6) 表 1,2 及び表 7〜20 に示したクロス集計表において、各世帯の 属性（住宅の所有形態、年収、世帯主の年路）と回答との関係につ いて、カイ自乗検定を用い独立性の検定を行った結果を表の右上に 米印で示した。有意水準 0.001 で両者の間に関連性があると言える 場合は「***小有意水淮 0.01 で関連性があると言える場合は「* *」、有意水準 0.05 で関連性があると言える場合は「*」とした。

注 7）表 1,2 及び表 7〜20に示したクロス集計表において、各カテゴ リの調整残差の值から、母集団の比率に関する各世帯属性間の差に ついて Z検定を行った結果を各カテゴリの比率の右横に米印及び スラッシュで示した。有意水準 0.01 で他の属性に比べ比率が大き いと言える場合は「ネ゙」、逆に小さいと言える場合は「//小有意水 準 0.05 で他の属性に比べ比率が大きいと言える場合は「゙」、逆に 小さいと言える場合は「/」とした。

注 8 ）公営住宅は、基本的には収入分位 $25 \%$ 以下の世帯を対象としてい る。今回のアンケート調查結果においても低家貨の公営住宅への入 居希望は主に従前の借家層の比率が高いため、静岡県の借家世帯の 平均世帯構成人数を見てみると 2.38 人/世帯で、2人世帯の収入 分位 $25 \%$ の年収は、3,824,000 4,151,999 円であるため、目安と する世帯収入区分の 1 つとして、400万円未満という区分を設定し た。

注 9) 図 2 に示した 3 ケースについては、すべて軸 1 、軸 2 ともカイ自乗 検定を行った結果、有意水淮 0.01 で世帯属性と回答の 2 つのカテ コリスコア間に関連性があると言えた。

注 $10 ）$ 住宅の所有形態別・世帯年収区分別の世帯数については、住宅・ 土地基本調查に基づき、市、区及び一定の規模以上の町村別に把握 することができる。

注 11 1)「応急仮設住宅」及び「公営住宅への一時入居」の潜在需要数に ついて、静岡市を例に取り、表 23 と静岡県の第 2 次地震被害想定 （1993）結果、平成 4 年の住民基本台帳（世帯数）、平成 5 年の住 宅統計調查結果（世帯属性別比率）を用い試算した値と、「阪神・ 淡路大震災における兵庫県内の家屋全壊世帯数を第 2 次地震被害 想定における大破世帯数に換算した值」と「阪神・淡路大震災にお いて結果として応急仮設住宅及び公営住宅へ一時入居した世帯数」 の比率を前出の第 2 次地震被害想定 (1993) の結果としての住宅 大破世帯数に掛け合わせて求めた值とを比較してみたところ、䛀 神・淡路大震災の被害量と対策の実績値の比率から概算した場合は、 1 万 9 千世帯であるのに対し、表 23 を使って求めた応急住宅対策 に関する潜在需要は、 2 万 9 千世帯と前者の約 1.5 倍となった。前 者は、阪神・淡路大震災の際の対策供給側の制約条件を含んだ上で の実績値を用いているのに対し、後者は、立地場所や供給量など、 対策供給側の制約条件を考慮する前の、潜在需要を求めたものであ る。従って、従前住宅からの距離などの条件設定によっては、一部 の需要が顕在化しない場合もある。

(2001年 1 月 9 日原稿受理, 2001 年 6 月 18 日採用決定) 